Edukatif : Jurnal Ilmu Pendidikan Volume 3 Nomor 1 Tahun 2021 Halm 75 - 83 EDUKATIF: JURNAL ILMU PENDIDIKAN

Research \& Learning in Education

https://edukatif.org/index.php/edukatif/index

\title{
Hakikat Belajar Konsep pada Peserta Didik
}

\author{
Biasri Suarim $^{1 凶}$, Neviyarni $^{2}$ \\ Universitas Negeri Padang, Sumatera Barat, Indonesia ${ }^{1,2}$ \\ E-mail : biasrisuarim80@ gmail.com ${ }^{1}$, neviyarni.suhaili911@ gmail.com $^{2}$
}

\begin{abstract}
Abstrak
Artikel ini membahas tentang analisis tahapan dalam belajar konsep menggunakan rujukan dari kajian literatur yang relevan, dalam konsepnya belajar konsep merupakan kegiatan manusia itu dapat mengkategorikan berbagai stimulus-stimulus yangmereka hadapi. Konsep-konsep merupakan kategori-kategori yang kita berikan padastimulus-stimulus yang ada dilingkungan kita. konsep yang ada di dalam strukturkognitif individu merupakan hasil dari pengalaman yang ia peroleh. Jika keadaannyademikian, sebagian konsep yang dimiliki individu merupakan hasil dari proses belajaryang mana proses dari hasil belajar ini akan menjadi pondasi (building bloks) dalamstruktur berfikir individu.
\end{abstract}

Kata kunci: belajar konsep

\section{Abstract}

This article discusses the analysis of stages in concept learning using references from relevant literature studies, in which concept learning is a human activity that can categorize the various stimuli they face. Concepts are the categories that we assign to stimuli in our environment. the concepts that exist in the individual's cognitive structure are the result of the experiences he has acquired. If this is the case, some of the concepts possessed by individuals are the result of the learning process in which the process of learning outcomes will become the foundation (building blocks) in the structure of individual thinking.

Keywords: learn concepts

Copyright (c) 2021 Biasri Suarim, Neviyarni

$\triangle$ Corresponding author

Email : biasrisuarim80@gmail.com

DOI $\quad:$ https://doi.org/10.31004/edukatif.v3i1.214

ISSN 2656-8063 (Media Cetak)

ISSN 2656-8071 (Media Online) 


\section{PENDAHULUAN}

Pada dasarnya manusia mempunyai kapasitas untuk megeneralisasikan suatu yang telah mereka pelajari ke dalam situasi baru, yang kemudian membantu mereka mempelajari konsep. Konsep tersebut memberikan suatu kemantapan kepada manusia untuk melakukan interaksi dengan lingkungannya. Konsep pembelajaran memberikan peluang kepada manusia untuk berada diatas keragaman dan ketidakterbatasan lingkungan dan memperlakukan peristiwa-peristiwa yang memiliki properti yang sama sebagai suatu kelompok. Umpamanya, pada saat anak-anak mempelajari konsep 'anjing', mereka mengelompokkan contoh-contoh dari jenis anjing tersebut. Mereka mempelajari bahwa label 'anjing' dapat digunakan untuk hal tertentu, dan lebih penting lagi mereka mempelajari bahwa 'anjing' mengacu kepada kelompok tertentu yang memiliki properti atau bentuk yang sama. Jika label 'anjing' tersebut digunakan untuk seekor anjing tertentu saja, umpamanya anjing milikinya saja, maka ini bukan merupakan pembelajaran konsep. Secara umum pembentukan konsep mengacu kepada pemilihan contoh yang cocok dan penolakan atau pemisahan contoh-contoh yang tidak cocok.

Pembelajaran konsep sebagai topik di dalam psikologi yang membentuk jalan antara proses diskriminasi stimulus yang lebih sederhana, respon belajar, dan formasi asosiasi satu menyampaikan dan proses berpikir lengkap, memberi alasan, dan memecahkan masalah pada sisi lain. Kesimpulannya, pembelajaran konsep tidak menghadirkan ketidakjelasan dan kecacatan dari proses yang lebih sederhana melibatkan pelajaran lisan. Sedangkan dipelajaran lisan tugas seperti rekaman dipasangkan dan bebaskan daya ingat untuk belajar, bisa dilihat bahwa manusia boleh terlibat dalam aktivitas konseptual.Konstruktivisme yang menekankan bahwa pengetahuan dibentuk oleh siswa yang sedang belajar, dan teoriperubahan konsep yang menjelaskan bahwa siswa mengalami perubahan konsep terusmenerus, sangat berperan dalam menjelaskan mengapa seorang siswa bisa salahmengerti dalam menangkap suatu konsep yang ia pelajari.

Kostruktivisme membantu untuk mengerti bagaimana siswa membentuk pengetahuan yang tidak tepat. Belajar yang efektif dapat membantu siswa untuk meningkatkan kemampuan yang diharapkan sesuai dengan tujuan yang ingin dicapai. Untuk meningkatkan cara belajar yang efektif perlu memperhatikan kondisi internal yaitu kondisi yang ada di dalam diri siswa itu sendiri misalnya kesehatannya, selain itu juga memperhatikan kondisi eksternal yang merupakan kondisi yang ada di luar diri pribadi manusia, misalnya suasana belajar siswa. Keberhasilan proses belajar ini dapat terlihat dari prestasi akademik siswa Hal yang harus disadari saat ini adalah pentingnya belajar konsep tentang sesuatu. Konsep yang dimaksud disini tidak lain dari kategorikategori yang kita berikan dari stimulus atau rangsangan yang ada di lingkungan kita.

Konsep yang ada di dalam struktur kognitif individu merupakan hasil dari pengalaman yang ia peroleh. Jika keadaannya demikian, sebagian konsep yang dimiliki individu merupakan hasil dari proses belajar yang mana proses hasil dari proses belajar ini akan menjadi pondasi (building blocks) dalam struktur berpikir individu. Konsep-konsep inilah yang dijadikan dasar oleh seseorang dalam memecahkan masalah, mengetahui aturan-aturan yang relevan, dan hal-hal lain yang ada keterkaitannya dengan apa yang harus dilakukan oleh individu.Definisi konsep menurut sebagian besar orang adalah sesuatu yang diterima dalam pikiran atau ide yang umum dan abstrak. Menurut salah satu ahli, konsep adalah suatu abstraksi yang mewakili suatu kelas objek, kejadian, kegiatan, atau hubungan yang mempunyai atribut yang sama Croser, (1984) . Tujuh dimensi konsep menurut Flavell (1970) adalah: Atribut Setiap konsep memiliki sejumlah atribut yang berbeda. Contoh-contoh konsep yang harus mempunyaiatribut yang relevan, termasuk juga atribut yang tidak relevan, termasuk juga atribut yang tidak relevan. Contoh-contoh konsep meja harus mempunyai suatu permukaan yang datar dan sambungan-sambungan yang mengarah ke bawah yang mengangkat permukaan itu dari lantai. Atribut dapat berupa fisik, seperti warna, tinggi, bentuk, atau dapat juga berupa fungsional,Struktur menyangkut cara terkaitnya atau tergabungnya atribut atribut itu. Berikut tiga macam struktur yang dikenal: 
a. Konsep Konjungtif, yaitu konsep yang didalamnya terdapat dua atau lebih sifat sehingga dapat memenuhi syarat sebagai contoh konsep yang sesuai Misalnya : seorang aktris adalah seorang wanita yang bermain dalam film. Dua atribut yaitu wanita dan bermain dalam film harus ada agar dapat mewakili konsep artis.

b. Konsep disjungtif, adalah konsep yang didalamnya satu dari dua atau lebih sifat harus ada. Konsep paman merupakan konsep disjungtif. Paman dapat merupakan kakak, ibu, atau ayah seorang pria yang menikah dengan kakak wanita ayah atau ibu dan juga pedoman.

c. Konsep relasional, menyatakan hubungan tertentu antara atribut konsep. Kelas sosial merupakan suatu contoh konsep relasional. Kelas sosial ditentukan oleh hubungan antara pendapatan, pendidikan, jabatan atau pekerjaan dan faktor lainnya.

d. Keabstrakan

Konsep-konsep dapta dilihat dan konkret atau konsep itu terdiri atas konsep konsep lain. Suatu segitiga dapat dilihat, keinginan lebih abstrak Keinklusifan Hal ini ditunjukan pada jumlah contoh yang terlibat dalam konsep itu. Bagi seorang anak kecil, konsep kucing ditunjukkan pada seekor hewan tertentu, yaitu kucing keluarga. Bila anak itu telah mengenal beberapa kucing lainnya, konsep kucing akan menjadi lebih luas, termasuk lebih banyak contoh. generalitas/keumuman bila diklasifikasikan, konsep dapat berbeda dalam posisi superordinat atau subordinatnya. Konsep wortel adalah subordinat terhadap konsep sayuran, selanjutnya konsep sayuran subordinat terhadap konsep tanaman dapat dimakan. Makin umum suatu konsep, makin banyak asosiasi yang dapat dibuat dengan konsep lainnya.Ketepatann Suatu konsep menyangkut apakah ada sekumpulan aturan untuk membedakan contoh dengan noncontoh suatu konsep. Klausmeier (1977) Klausmeier (1977) mengemukakan empat tingkat pencapaian konsep, mulai dari tingkat konkret ke tingkat formal. Konsep pada tingkat formal merupakan konsep yang paling tepat sebab pada tingkat ini atribut-atribut yang dibutuhka konsep dapat didefenisikan kekuatan atau power kekuatan suatu konsep ditentukan oleh sejauh mana orang setuju bahwa konsep itu penting.

\section{METODE PENELITIAN}

Artikel ini membahas tentang analisis tahapan dalam belajar konsep, jenis metode penelitian ini adalah analisis kajian pustaka (literatur research) artikel ini akan memaparkan analisis jurnal ilmiah yang relevan dengan pembahasan yang sudah dipilih, adapun tahap- tahap dalam metode penelitian ini adalah (1) memilih artikel, (2) mengumpulkan data awal, (3) tantangan dari topik,(4) mengumpulkan data pendukung, (5) menghasilkan kesimpulan dan rekomendasi online.

\section{HASIL DAN PEMBAHASAN PENELITIAN}

\section{A. Pengertian Belajar Menurut Ahli}

Slameto (2003) : Belajar pada hakikatnya adalah suatu proses usaha yang dilakukan seseorang untuk memperoleh perubahan tingkah laku yang baru secara keseluruhan, sebagai hasil pengalamannya sendiri dalam interaksinya dengan lingkungan.

Trianto (2011) : Belajar sebagai perubahan pada individu yang terjadi melalui pengalaman dan bukan karena pertumbuhan atau perkembangan tubuhnya atau karekteristik seseorang sejak lahir.

Winkel ( 1987) : Belajar merupakan suatu aktivitas mental atau psikis, yang berlangsung dalam interaksi aktif dengan lingkungan, yang menghasilkan sejumlah perubahan yang relatif konstan dan berbekas.

Menurut Doris Andrias Harifa,( 2001 : 1 ) Belajar adalah mengerti sesuatu yang telah diketahui sepanjang hidup tetapi dengan pemahaman yang berbeda. 
Wittig (dalam Syah, 2003 : 65-66 ) belajar sebagai any relatively permanen change in an organism behavioral repertoire that accurs as a result of experience (belajar adalah perubahan yang relatif menetap yang terjadi dalam segala macam/keseluruhan tingkah laku suatu organisme sebagai hasil pengalaman).

Sugandi (2006: 9) menyebutkan bahwa pembelajaran merupakan suatu kumpulan proses yang bersifat individual, yang mengubah stimuli dari lingkungan seseorang ke dalam sejumlah informasi, yang selanjutnya dapat menyebabkan adanya hasil belajar dalam bentuk ingatan jangka panjang

Anitah (2011: 2.30) menyatakan pembelajaran merupakan suatu upaya untuk mencapai tujuan atau kompetensi yang harus di kuasai siswa.

Hamdani, (2011:72) Pembelajaran merupakan upaya guru untuk menciptakan iklim dan pelayanan terhadap kemampuan, potensi, minat, bakat, dan kebutuhan siswa yang amat beragam agar terjadi interaksi optimal antara guru dan siswa serta antarsiswa

\section{B. Hakikat Belajar Konsep}

Pada hakikatnya belajar konsep membantu untuk mengatasi keragaman yang spesifik dan tak terbatas dari lingkungaan dan untuk memperlakukan peristiwa-peristiwa yang memiliki sifat-sifat yang sama sebagai bagian dari suatu jenis atau kelompok tertentu. Muhibbin Syah (2010: 90) mengatakan bahwa "Belajar dapat dipahami sebagai tahapan perubahan seluruh tingkah laku individu yang yang relatif menetap sebagai hasil pengalaman dan interaksi dengan lingkunganya yang melibatkan proses kognitif'. Oleh karenanya, pemahaman yang benar mengenai arti belajar dengan segala aspek, bentuk, dan manifestasinya mutlak diperlukan olehh para pendidik khususnya para guru. Kekeliruan atau ketidaklengkapan persepsi mereka terhadap proses belajar dan hal-hal yang berkaitan dengannya mungkin akan mengakibatkan kurang bermutunya hasil pembelajaran yang dicapai peserta didik.

Belajar merupakan suatu perubahan yang terjadi melalui latihan atau pengalaman, dalam arti perubahan-perubahan yang disebabkan oleh pertumbuhan atau kematangan tidak dianggap hasil belajar; seperti perubahan-perubahan yang terjadi pada diri seorang bayi. Begitu pula jika dilihat dari sudut ilmu mendidik, belajar berarti perbaikan dalam tingah laku dan kecakapan-kecakapan manusia, atau memperoleh kecakapan-kecakapan dan tingkah laku yang baru. Jadi, perubahan yang terjadi pada proses belajar itu merupakan perubahan/perbaikan dari fungsi-fungsi psikis yang menjadi syaratyang mendasari perbaikan tingkah laku dan kecakapan-kecakapan.

Dapat dikatakan pembelajaran konsep mengupayakan individu untuk mampu merespon bentukbentuk yang relevan (berhubungan) dengan konsep tersebut dan tidak menghiraukan (ignore) bentukbentuk yang tidak relevan dengan mengidentifikasikannya. Dengan kata lain dari banyak kata, dan bisa dikatakann disempitkan lagi kepada hal yang lebih spesifik. Pembelajaran konsep dipandang sebagai sebuah kombinasi dari perbedaan antara kelompok-kelompok kejadian dengan generalisasi dalam kelompok-kelompok kejadian yang ada.

\section{Belajar Konsep Generalisasi dan Deskriminasi}

Dalam hal ini belajar konsep generalisasi dan deskriminasi berakar dari teori yang dikembangkan oleh Ivan Pavlov yaitu teori clasical conditioning. Kata clasical yang mengawali nama teori ini sematamata dipakai untuk menghargai karya Pavlov yang dianggap paling dahulu dibidang conditioning (upaya pengkondisian) dan untuk membedakannya dari teori conditioning lainnya Henry Gleitmen, (1986). Secaraa sederhana pengkondisian klasik merujuk pada sejumlah prosedur pelatihan dimana satu stimulus/ 
rangsangan muncul untuk menggantikan stimulus lainnya dalam mengembangkan suatu respon yang bersifat bisa memberikan hal yang sesuai bahwa prosedur ini dapat disebut klasik karena prioritas historisnya seperti dikembangkan oleh Pavlov Rita L. Atkinson, et.al, (1983:299). Fase-fase dalam teori clasical conditioning ini diantaranya, sebagai berikut:

\section{Fase Generalisasi}

Jadi setelah seekor hewan telah 'belajar' respons kondisi dengan satu stimulus, ada kemungkinan juga ia merespons stimulus yang sama tanpa latihan lanjutan. Jika seorang anak digigit oleh seekor anjing hitam besar, anak tersebut bukan hanya takut kepada anjing tersebut, namun juga takut kepada anjing yang lebih besar. Fenomena ini disebut generalisasi. Stimuli yang kurang intens biasanya menyebabkan generalisasi yang kurang intens. Sebagai contoh, anak tersebut ketakutannya menjadi berkurang terhadap anjing yang lebih kecil darinya.

2. Fase Diskriminasi

Jika pada fase diskriminasi kebalikan dari generalisasi adalah diskriminasi. Kalau generalisasi merujuk pada tendensi untuk merespons sejumlah stimuli yang terkait dengan respons yang dipakai selama training. Diskriminasi mengacu pada tendensi untuk merespons sederetan stimuli yang amat terbatas atau hanya pada stimuli yang digunakan selama training saja. Ketika seorang individu belajar menghasilkan respons kondisi pada satu stimulus dan tidak dari stimulus yang sama namun kondisinya pasti berbeda. Sebagai contoh, seorang anak memperlihatkan respons takut pada anjing galak yang bebas, namun mungkin memperlihatkan rasa tidak takut ketika seekor anjing galak diikat.

\section{Kajian Tentang Belajar Konsep}

Adanya pembentukan terhadap respon dapat dilihat dengan ada dua prosedur dasar dalam pembelajaran konseptual, yaitu: reception paradigm (paradima penerimaan) dan selection paradigm (paradigma seleksi). Pada paradigma penerimaan, stimulus dihadirkan secara acak atau telah ditetapkan sebelumnya oleh yang melakukan eksperimen dan subjek mengklasifikasikan masing-masing stimulus tersebut. Belajar merupakan hal yang sangat diperlukan bagi manusia Sementara itu pada paradigma seleksi, subjek diberikan keseluruhan bentuk dari stimulus pada permulaan eksperimen dan kemudian memilih stimulus, percobaan dilakukan secara berulang-ulang dan menginginkan adanya balikan (feedback). Ciri-ciri belajar konsep melibatkan stimulus (rangsangan), respon (tanggapan), dan beberapa bentuk umpan balik (feed-back) kepada learner (pelatih). Stimulus meliputi contoh positif dan contoh negatif, respon dapat memakai cara yang paling sederhana sampai kepada yang agak rumit, dan umpan balik diberikan sebagai pembetulan terhadap respon. Diketahui pembelajaran konseptual terdapat beberapa atribut dan aturan. Atribut merupakan sifat atau karakteristik stimulus yang relevan terhadap konsep. Konsep yang sederhana mungkin hanya memiliki satu saja atribut seperti warna, sedangkan konsep yang lebih rumit dari itu memiliki lebih banyak atribut, seperti warna dan rasa. Atribut dapat menegaskan sebuah aturan konseptual, maksudnya konsep terhadap sesuatu objek ada penguatan didalamnya.

Ada perbedaan antara belajar konsep (concept learning) dengan paired associate learning. Paired associate learning menghendaki pembelajaran respon tertentu terhadap suatu stimulus, jadi rasio antara stimulus dan respon adalah satu - satu. Sedangkan belajar konsep mencakup pembelajaran satu respon terhadap dua atau lebih stimulus, jadi rasio antara stimulus dengan respon bukan satu-satu, tetapi satu lawan banyak. Umpamanya, dalam kegiatan di sekolah dasar anak diajarkan konsep warna putih. Anak akan diberikan contoh warna putih dari sebuah objek seperti kertas putih dan dikatakan bahwa warna 
kertas ini adalah putih adalah putih. Kemudian anak tersebut diminta mengulangi respon yang sama ("putih") pada lembaran-lembaran kertas lain yang juga berwarna putih.

Untuk menyakinkan apakah sebuah konsep telah terbentuk perlu diperhatikan dua faktor. Pertama kita harus memberikan contoh objek (instance) tambahan untuk melihat apakah konsep tersebut telah dikelompok secara benar, dan kedua kita harus memberikan yang bukan contoh (noninstance) atau contoh yang salah untuk melihat apakah mereka mampu mengeluarkan bagian ini dari konsep yang telah terbentuk. Jadi pembelajaran konsep menghendaki sipelajar melakukan respon bentuk-bentuk yang relevan dari konsep tersebut dan tidak menghiraukan (ignore) bentuk-bentuk yang tidak relevan di dalam pengelompokan peristiwa.

\section{E. Faktor yang Mempengaruhi Pembelajaran Konsep}

Secara umum ada dua faktor yang mempengaruhi pembelajaran konsep yaitu variabel tugas (task variabel) dan variabel pelajar (learner variabel). Contoh-contoh dari variabel tugas tersebut adalah contoh negatif dan positif (positif and negatif instances), atribut yang relevan dan yang tidak relevan, stimulus abstrak dan stimulus nyata, umpan balik dan faktor temporal, dan aturan-aturan konseptual sehinga dapat memberikan apa yang dihara dari pembelajaran .

1. Contoh Positif dan Negatif

Dalam hal positive dan negative instaces, ditemukan bahwa manusia cenderung menggunakan positive instance dalam mempelajari konsep ketimbang negative instances. Hal ini disebabkan oleh kurangnya informasi pada negative instances, dan manusia lebih banyak bertemu dengan positive intances daripada negative intances yang harus menyesuaikan.

2. Atribut yang Relavan dan Tidak Relevan

Berkaitan dengan atribut yang relevan dan yang tidak relevan, ada dua hal yang harus diperhatikan. Pertama semakin banyak jumlah atribut yang tidak relevan didalam sebuah tugas pembelajaran konsep, semakin sulit tugas pembelajaran tersebut. Kedua, semakin banyak atribut redundant (perulangan/sama) yang relevan, semakin mudah pembelajaran konsep. Yang dimaksud dengan atribut redundant yang relevan adalah bentuk-bentuk yang berhubungan secara sempurna, sehingga bentuk tersebut dapat dijadikan dasar peramalan yang sahih untuk sebuah konsep. Umpamanya setiap lingkaran diberi warna biru, setiap segitiga diberi warna kuning dan setiap segiempat diberi warna merah. Suatu yang relevan sehinga bisa dijadikan sebagai acuan dari atribut

3. Stimulus Abstrak dan Stimulus Nyata

Kejelasan kunci (cues) yang relevan dapat pula membantu memudahkan pembelajaran konsep. Anakanak lebih cepat mempelajari konsep warna daripada mempelajari konsep perbedaan dimensi atau bentuk. Mereka juga lebih mudah mempelajari konsep yang kongrit seperti 'mobil', 'rumah', 'anjing', dll daripada konsep abstrak. Jika kunci lebih mirip, yang mengakibatkan berkurangnya kejelasan, maka pembelajaran konsep semakin sulit. Umpamanya, pembelajaran konsep 'socialisme' atau 'demokrrasi' akan lebih sulit karena kedua konsep tersebut memiliki banyak kunci (cues) yang tumpang tindih.

4. Umpan Balik dan Faktor Temporal/ Waktu

Balikan (feedback) merupakan faktor yang mempengaruhi keberhasilan pembelajaran konsep. Feedback akan memberikan tanda bahwa respon yang dilakukan benar atau tidak. Bahkan ia dapat digunakan untuk mengarahkan respon berikutnya di dalam tugs-tugas konseptual. Penggunaan kata 'benar' dan 'salah' sudah merupakan balikan yang berarti dalam pembelajaran konsep, tetapi hal ini 
tidak banyak berpengaruh pada manusia. Untuk manusia, postfeedback delay (penundaan antara balikan yang diberikan untuk sebuah trial dan pemberian stimulus berikutnya) mempunyai pengaruh yang lebih besar dalam kinerja (performance). Bila postfeedback delay diperpanjang pembelajaran konsep akan lebih terbantu.

5. Aturan-aturan Konseptual

Cara penggabungan hukum konseptual (conseptual rules) akan menentukan kemudahan pembelajaran konsep. Konsep yang menggunakan hukum konjungtif (conjuntive rules), hukum sebuah konsep dimana kedua atribut harus digabungkan, seperti 'meja bundar', lebih mudah dipelajari dari pada konsep yang menggunakan hukum kondisional (conditional rules), jika A, maka B dan biconditional, yakni jika A maka B, maka A.

6. Memori dan Intelegensi

Faktor terakhir yang mempengaruhi pembelajaran konsep adalah memory dan intelegensi. Pembelajaran konsep ternyata tidak hanya tergantung pada karakteristik tugas tetapi juga pada karakteristik sipelajar. Memori dan kecerdasan merupakan variabel individu yang berbeda yang mempengaruhi kemudahan pembelajaran konsep. Untuk mengetahui konsep dengan jelas seseorang perlu mengingat informasi yang berkaitan dengan konsep tersebut. Begitu pula dengan kecerdasan, semakin cerdas seseorang memecahkan tugas konseptual semakin, cepat ia mempelajari sebuah konsep. Kemudian Memori dan kecerdasan akan berbeda pada setaip individu.

\section{F. Teori-teori Belajar Konsep}

Belajar konsep memiliki beberapa teori, sebagai berikut:

1. Teori Asosiasi Stimulus Respon

Menurut teori Asosiasi ini, kegiatan pembelajaran akan efektif apabila interaksi antara pendidik dengan peserta didik dilakukan melalui stimulus dan respons (S-R). Kegiatan pembelajaran adalah proses menghubungkan stimulus (S) dengan respons (R). Berdasarkan teori ini, pembelajaran makin efektif apabila peserta didik makin giat belajar dan makin tinggi kemampuannya dalam menghubungkan simulus dan respons. Prinsip-prinsip yang digunakan dalam teori ini adalah: kesiapan (readiness) berkaitan dengan motivasi peserta didik, latihan (exercise) yaitu kegiatan berulang peserta didik dalam menghubungkan stimulus-respons, dan pengaruh (effect) yang berhubungan dengan hasil kegiatan dan manfaat yang dirasakan langsung oleh peserta didik dalam dunia kehidupannya. Prinsip 'pengaruh' berkaitan pula dengan penciptaan suasana, penghargaan, celaan, hukuman, dan ganjaran.

Jika kita telaah lebih lanjut, di samping hal-hal positif dari teori Asosiasi, kita menemukan adanya hal-hal yang negatif dari teori ini. Di antaranya, teori ini mengenyampingkan peranan minat, kreativitas, dan apirasi peserta didik. Selain itu teori ini juga lebih menekankan peluang belajar individual, dominasi kemampuan pendidik atau sumber belajar lainnya dalam menciptakan stimulus Sudjana, (2000:178). Karena tidak semua perilaku belajar dapat dijelaskan dengan pelaziman, teori Asosiasi biasnya menambahkan konsep belajar sosial (social learning) dari Bandura. Menurut Bandura, belajar terjadi karena peniruan (imitation). Kemampuan meniru respons adalah penyebab utama belajar. Teori belajar sosial memiliki beberapa konsep dasar. Konsep konsep tersebut adalah:

a. Pemodelan (modelling), seseorang belajar dengan cara meniru perilaku orang lain dan pengalaman vicarious yaitu belajar dari keberhasilan dan kegagalan orang lain; 
b. Fase Belajar, terdiri dari fase perhatian terhadap model (attentional phase), fase mengendapkan hasil memperhatikan model dalam pikiran pebelajar (retention phase), fase menampilkan ulang perilaku model oleh pebelajar (reproduction phase) dan fase motivasi (motivation phase) ketika peserta didik berkeinginan mengulang-ulang perilaku model yang mendatangkan konsekuensikonsekuensi positif dari lingkungan;

c. Belajar Vicarious, seseorang belajar dengan melihat apakah orang lain diberi ganjaran atau hukuman waktu terlibat dalam perilaku-perilaku tertentu;

d. Pengaturan-sendiri (self-regulation), manusia mengamati, mempertimbangkan, memberi ganjaran atau hukuman terhadap perilakunya sendiri.

2. Teori Pengujian Hipotesis

Menurut Teori belajar konsep lain adalah teori pengujian hipotesis (Hypothesis-testing theory). Teori ini selalu menekan pada prinsip bahwa manusia lebih aktif dalam melaksanakan tugas dalam arti bahwa ia aktif memilih dan mencoba atau menguji kemungkinan pemecahan masalah. Teori ini menekankan pada pentingnya pemilihan hipotesis, memilih karakter tugas pemecahan masalah, sehingga proses ini melibatkan teori kognitif. Dalam menerapkan teori ini kita dapat memilih dua strategi yakni conservative focusing, dan strategi focus gambling. Dengan strategi conservative focusing, subjek diminta untuk memilih respon diantara beberapa respon sesuai dengan hipotesis awalnya, kemudian diberi balikan dengan kata 'benar', maka ia telah mempelajari konsep tersebut. Sedangkan didalam focus gambling, subjek diberikan kesempatan dan memvariasikan dua atau lebih atribut pada saat menguji hipotesisnya. Biasanya dengan strategi yang kedua, bila berhasil dengan baik, subjek akan lebih cepat mempelajari konsep yang sesuai dengan apa yamenjadikan sebuah penguji yang ada tersebut

3. Teori Proses Informasi

Menurut Henry C. Ellis (1978:78). ada tiga proses yang terjadi di dalam proses informasi yaitu ecoding, Storage dan Retrieval. Teori pembelajaran konsep yang biasa diterapkan adalah Information-Processing theories atau teori pengolahan informasi. Teori ini menekan pada ciri pengolahan informasi manusia dalam belajar konsep. Teori ini diangkat dari analogi kerja konputer dan memandang belajar konsep dalam artian urutan proses pengambilan keputusan oleh sipelajar.

\section{G. Beberapa Prinsip-prinsip Praktis dalam Belajar Konsep}

1. Think of new examples of concept, memikirkan contoh-contoh baru untuk konsep tersebut.

2. Use both positive and negative instances, menggunakan kejadian atau contoh-contoh positif dan negatif.

3. Use a variety of example, menggunakan contoh-contoh yang bervariasi.

4. High-light relevant features, berikan penekanan pada bentuk-bentuk relevan, untuk menhindari terjadinya kesalah pahaman yang ada.

\section{KESIMPULAN}

Pembelajaran konsep merupakan salah satu pembelajaran yang yang memberikan kesempatan kepada peserta didik untuk mengkonstruksi dan juga menemukan sendiribaik itu materi yang akan dipelajari baik itu konsepnya berupa benda yang diperagakan kepada peserta didik sehinga ada konsep pada peserta didik 
tersebut dan memberikan konsep dala belajar sehinga peserta didik tidak kebingungan pada saat belajar karena peserta didik disiapkan sebelum memulai pembelajaran dan konsep tersebut yang menjadi rujukan dan acuan dalam proses belajar konsep itu yang utama dalam melakukan pembelajaran lebih lanjut pembelajaran konsep merupakan pembelajaran yang menjadikan suatu kesiapan bagi peserta didik yang mana dari peserta didik tidak lagi membingunkan dalam proses belajar karena telah menyiapakn apa yang akan di pelajari maka dengan konsep itu lah pembelajaran berjalan dengan baik

\section{DAFTAR PUSTAKA}

Anas Sudijono. 2005. Pengantar Statistik Pendidikan. Jakarta: Raja Grafindo Persada.

Anitah, Sri dkk. 2011. Strategi pembelajaran di SD. Jakarta: Universitas Terbuka

Dahan, Ratna Willis. 2006 Teori-teori Belajar dan pembelajaran, Jakarta : Erlangga

Ellis Henry C. 1978. Fondamentals Of Human Learning, Memory And Cognition (2 ${ }^{\text {nd }}$ Edition). Lowa: Wm. C. Brown Company Publisher.

H. C. Ellis 1978 Fundamentals of Human Learning, Memory and Cognition Fundamental of Psychology Series

Harifa, A. (2001). Pembelajaran. Jakarta: Bumi Aksara

Hamdani. 2011. Strategi Belajar Mengajar. Bandung: Pustaka Setia.

Muhibbin Syah. 2010. Psikologi Pendidikan, Bandung : PT Remaja Rosdakarya

Rita L. Atkinson. et.al,.1983. Intrudoction To Psycology, Eight Edition. Terjemah, Nurjannah Taufiq,

Rukmini Barhana, Editor Agus Gharma, Michael Adryanto, Jakarta: Erlangga.

Sudjana S. 2000. Strategi Pembelajaran. Bandung: Penerbit Falah Production.

Syah, Muhibbin. 2003. Psikologi Belajar. Jakarta : Raja Grafindo Persada

Slameto. 2003. Belajar dan Faktor-Faktor Yang Mempengaruhi. Jakarta: Rineka Cipta.

Sugandi, Achmad. 2006. Teori Pembelajaran. Semarang: Universitas Negeri Semarang Press.

Tim Pengembangan MKDP Kurikulum dan Pembelajaran Kurikulum \& Pembelajaran. 2006. Bandung : Jurusan Kurikulum dan Teknologi Pendidikan Fakultas Ilmu Pendidikan Universitas Penddikan Indonesi

Winkel, W.S. 1987. Bimbingan dan Konseling di Institusi Pendidikan. Jakarta : Gramedia. 